\title{
КЛІНІКО-ПСИХОЛОГІЧНА ОЦНКА ОБМЕЖЕНОЇ ЗДАТНОСТІ «РОЗУМІТИ, ОЦІНЮВАТИ ТА ПРИЙМАТИ РІШЕННЯ» В ЦИВІЛЬНОМУ ПРОЦЕСІ
}

УдК: 616.853-052

\section{Завязкіна Наталія Володимирівна}

Кандидат психологічних наук, доцент факультету психології Київського національного університету імені Тараса Шевченка, м. Київ (Украӥна)

\begin{abstract}
Анотація. В умовах зростаючих вимог до обтрунтування експертних висновків, динамічних змін в законодавстві виникає потреба в створенні цілісної системи, яка б сприяла об’єднанню сучасних та традиційних принщипів діагностики психічних розладів з принщипами судово-експертної діяльності з використанням сучасних методів психологічної діагностики. При проведенні експертиз у циивільному процесі однією з найважливіших задач стає розробка діагностичних критеріїв обмеженої дієздатності, встановлення «нижньої» та «верхньої» межі, оскільки, часткова можливість обмежено дієздатного громадянина нести відповідальність (розуміти сутність власних вчинків, необхідність виконання зобов'язань, здатність утримувати їх в пам'яті, рівень активності, можливість виконувати дї в умовах зовнішньої регламентації $з$ боку піклувальника) становить одну з підстав диферениіації обмеженої дієздатності та недієздатності.
\end{abstract}

Ключові слова: психологічна оиінка, обмежена дієздатність, ичивільний процес, психодіагностика, психологічна експертиза

Постановка проблеми. На сьогоднішній день необхідність участі експертапсихолога у вирішенні питань осудності, обмеженої осудності, неосудності та дієздатності, обмеженої дієздатності, недієздатності не викликає сумніву, оскільки аналіз впливу психічної патології на інтелект і волю вимагає використання загально психологічних, психодіагностичних та патопсихологічних знань, які мають свої феноменологічні ознаки та не зводяться лише до психіатричних. Феноменологічна оцінка психіатричного розладу зі встановленням психопатологічних критеріїв повинна бути доповнена психологічним та ситуаційним аналізом [1-4].

В багатьох країнах поняття «обмеженої» або «часткової» дієздатності закріплено на рівні законодавства для неповно- 
літніх, осіб, які страждають на психічні захворювання внаслідок вживання ПАР, осіб, які страждають на психічні розлади (якщо ступінь вираженості цих змін не позбавляє їх повністю дієздатності, але ж потребують призначення помічника). В цих випадках рішення щодо обмеженої дієздатності стосується в першу чергу заключення угод 3 нерухомістю. Тобто ці угоди обмежено дієздатний громадянин може заключати лише зі згоди довіреної особи. У всіх державах для вирішення питання щодо дієздатності, необхідне рішення суду.

Особливе місце займає питання кримінальної відповідальності недієздатних громадян. Деякі фахівці дотримуються думки, що відсутність дієздатності для учасника кримінально-процесуальних відносин має різні наслідки. Якщо недієздатним є потерпілий, то його інтереси представляє законний представник. Якщо недієздатною є особа, що вчинила суспільно-небезпечне діяння, то вона звільняється від кримінальної відповідальності. Встановлення кримінально-процесуальної дієздатності має бути обов'язковим в кримінальному судочинстві. Крім того, у кримінальному процесі не можуть самостійно представляти свої інтереси особи старечого віку і довгожителі, незалежно від того, визнані вони недієздатними або ні, а також особи, що перенесли сильні стреси, важкі соматичні захворювання, мають дефекти органів, що сприяють отриманню інформації (слух, зір).

\section{Аналіз останніх досліджень і публі-} кацій. Психологічні аспекти теорії судовопсихологічної експертизи розроблялися протягом багатьох років відомими вченими, зокрема М. М. Кочєновим, Ю. М. Антоняном, Л. М. Юр'євою, Н. В. Алікіною, М. В. Костицьким, Й. А. Кудрявцевим, В. В. Нагаєвим, Ф. С. Сафуановим, О. Д. Ситковською та ін.

Останнім часом все більшої актуальності набуває інтеграція накопичених даних щодо особистості учасника конфліктної події цивільного змісту. Становленню необхідності комплексного вивчення портрету особистості, поєднання аналітичного розуміння 3 системним підходом в оцінці даних, присвячені роботи Г. С. Костюка, Л. Ф. Бурлачука, Т. М. Титаренко, П. К. Анохіна, Б. Г. Ананьєва, А. А. Абульханонової-Славскої, Ф. Ю. Василюка, О. С. Чабана, В. О. Моляко, Н. В. Чепелєвої та ін. Підкреслення специфіки психологічної структури особистості, своєрідності протікання психічних процесів і виникнення тих чи інших тимчасових психічних станів та визначених вчинків стає можливим саме грамотному та доцільному використанню психологічних знань про призначенні та проведенні судових експертиз.

При дослідженні психічного здоров'я експерт орієнтується в тому числі на Міжнародну класифікацію хвороб 10 перегляду (МКХ-10), у відповідності з якою психічні розлади і розлади поведінки визначені до рубрик F00-F99 -Психічні розлади і розлади поведін- 
ки. Закладена в ній операціональна модель діагностики, заснована на виявленні певної сукупності симптомів та забезпечує достатню відтворюваність діагностичного висновку, однак часто не дозволяє обгрунтувати експертний висновок. Традиційний категоріальний підхід до діагностики розкриває клінікодинамічні особливості психічного розладу, забезпечуючи надійність ретроспективного i прогностичного експертного висновку, однак не виключає «розширювальної» діагностики. У МКХ-10 з'явилися терміни, що раніше не використовувалися в нашій країні, такі як легкий когнітивний розлад, шизотиповий розлад, панічний розлад, генералізований тривожний розлад, посттравматичний стресовий розлад, розлад адаптації, соматоформні розлади і ряд інших, тобто по-новому стали позначатися багато ключових категорій психопатології. Серед них - невротичні, пов'язані із стресом i соматоформні розлади, поведінкові синдроми, пов'язані з фізіологічними порушеннями і фізичними факторами, розлади зрілої особистості та поведінки у дорослих тощо. Таким чином, МКХ-10 ввела в психопатологію цілий ряд нових теоретичних принципів, серед яких найважливішим вважають принцип операціональності, згідно з яким поняття можуть визначатися тільки через сукупність відтворних експериментально-вимірювальних операцій. Слідством такого методологічного повороту стало те, що діагностика психічних розладів почала здійснюватися не на основі клінічного досвіду лікаря або інтуїтивного прогнозування динаміки захворювання, а на основі реєстрації обмеженої кількості відносно незалежних стандартних ознак. Причому ці ознаки повинні однаково описуватися, а їх застосування здійснюють відповідно до заздалегідь заданої алгоритмізованої процедури.

Як вказують багато авторів, при вирішенні питання здатності громадянина приймати свідомі дії, постає двояке етичне питання. Право будь якого громадянина, починаючи 3 відповідного віку, самостійно приймати рішення, які торкаються його інтересів, a, 3 іншого боку, моральна відповідальність суспільства та обов'язки держави захищати інтереси громадян, в тому числі тих, хто страждає на психічні розлади, які обмежують їх право приймати рішення. Тому за останні роки, оцінка правоздатності від окремих випадків розширилася до окремої галузі судової експертизи з великою кількістю різноманітних досліджень та розробкою специфічних теоретикометодологічних підходів та експертних моделей.

Якщо пригадати загально відоме визначення методології конкретної галузі наукового знання, то стає очевидним, що ним наголошується на тому, що методологія конкретної частини науки не зводиться до системи методів дослідження, які в цій галузі використовуються. Тобто, методологія не прирівнюється до системи методів, бо це мало би надто практичний та спрощений підхід. Методо- 
логія - це систематизоване, теоретичне знання (в т.ч. про методи пізнання та методи формування теоретичних конструкцій та теорій), система ідей, та, безумовно, методів дослідження [5]. Виходячи з цього, загальна теорія судової експертології - це методологія цієї галузі знань в цілому та основа для іiі більш окремих теорій. У судовій експертизі виділяють методи загально-наукові (іх мета - використання методів науки для пізнання закономірностей сутності її предмета, його розкриття, систематизації знань) та методи практичної експертної діяльності (іх мета - вирішення конкретних експертних задач). До числа методів, які використовуються для пізнання та аналізу в експертній діяльності, входять узагальнення, порівняльний аналіз, абстрагування, моделювання, комплексування, системний аналіз, класифікація, а також інформаційний підхід, діяльний підхід, правовий аналіз тощо.

Метою даного дослідження $є$ уточнення можливостей використання принципів психологічної діагностики психічних розладів при проведенні експертиз у цивільному процесі.

\section{Виклад основного матеріалу та ре-} зультатів дослідження. Однією 3 найважливіших задач, яку було виділено, стає розробка діагностичних критеріїв обмеженої дієздатності та встановлення «нижньої» та «верхньої» межі, оскільки, часткова можливість обмежено дієздатного громадянина нести відповідальність (розуміти сутність власних вчинків, необхідність виконання зобов'язань, здатність утримувати їх в пам'яті, рівень активності, можливість виконувати дії в умовах зовнішньої регламентації з боку піклувальника) складають одну з підстав диференціації обмеженої дієздатності та недієздатності.

Умовно виділяють два етапи обгрунтування експертного висновку: на першому етапі обгрунтування аналізується симптоматика психічного розладу, що дозволяє затвердити або відкинути належність психічного стану до психічного розладу. На другому етапі на основі отриманих даних про психопатологічні та патопсихологічні властивості психічного стану здійснюється порівняння, співставлення наявної інформації з вимогами психологічного критерію певної правової категорії (неосудності, недієздатності та ін.) [6-8]. За результатами аналізу та співставлення даних, котрі стосуються медичного і психологічного критеріїв, формулюється висновок про психічний стан підекспертного під час вчинення юридично значущого діяння з обгрунтуванням його відповідності юридичному критерію [9$11]$.

\section{Розглянемо випадок 3 практики.}

При призначенні експертизи, на вирішення експертів було поставлено наступне запитання:

1. Чи розуміє значення своїх дій та чи може керувати ними К., чи потребує призначення опіки чи піклування?

3 дослідницької частини з'ясовано, що 
до районного суду міста ... звернулась 3. щодо питання дієздатності свого сина. Як вбачається 3 даної заяви, її син К. являється інвалідом II групи в зв'язку з психічним захворюванням, перебуває на обліку у психіатра. 3 медичної документації вбачається, що спадковість психічними захворюваннями не обтяжена. Розумовий розвиток без особливостей. У дитячому віці хворів простудними захворюваннями. До школи пішов своєчасно і навчався добре. Має середню освіту, служив в армії. Вперше психічний стан змінився 14 років тому, коли з'явилися коливання настрою безсоння, замкнутість, а потім приєдналися слухові галюцинації, спочатку за типом діалогу, а згодом за типом псевдогалюцинацій. Відчував вплив, було відчуття зробленості. При першому стаціонарному лікуванні не проявляв ініціативи в бесіді, був в'ялим, монотонним; скаржився на слухові галюцинації всередині голови; говорив про те, що голоси впливають спеціально, може перевіряють, відчував здавлення на голову та тіло. При психологічному дослідженні відмічались рішення, в яких він актуалізував латентні ознаки предметів; помилкові рішення не піддавались корекції. Відмічались паралогічні висловлювання; описання сюжетних малюнків були односкладові, з неадекватним виділенням емоційного підтексту. Був виписаний 3 діагнозом «Шизофреноподібний психоз, галюцинаторно-параноїдний синдром». У подальшому неодноразово був госпіталізований у зв'язку 3 погіршеннями психічного стану, став пиячити, ліки приймав нерегулярно. При останній госпіталізації був некритичним до свого стану, виписаний з діагнозом «Шизофренія параноїдна форма, безперервно-прогредієнтний тип перебігу, стійкий виражений галюцинаторно-параноїдний синдром, глибокий апатикодисоціативний дефект». 3 записів дільничого психіатра відомо, що звертався зі скаргами на слухові галюцинації, тривогу, страх; необережно приймав підтримуюче лікування, періодично відчував «голоси» та стеження. Контакт 3 хворим був формальним, зазначено, що хворий емоційно сплощений, мав дисоціативні судження та розірване мислення.

За матеріалами цивільної справи, додатково на запит експертів надана ксерокопія трудової книжки, з якої вбачається, що хворий звільнився з роботи за власним бажанням. Також у матеріалах цивільної справи мається характеристика мешканців, в якій зазначено, що вони знають К. багато років, за час сумісного проживання претензій до його поведінки не мають. Він має спокійний характер, ввічливий, доброзичливий, завжди охайно одягнутий. Відхилень від нормального психологічного стану не помічали.

Також у матеріалах цивільної справи мається пояснення дільничого лікаряпсихіатра, який пояснив, що К. страждає хронічним психічним захворюванням, перебуває на диспансерному обліку, є інвалідом II групи. У зв'язку з тим, що у суду виникло ряд 
питань у галузі судової психіатрії, була призначена амбулаторна судово-психіатрична експертиза.

При клінічному дослідженні експертами був встановлений психічний, неврологічний та соматичний стан підекспертного.

Зазначено що у психічному стані підекспертний: контакту доступний, орієнтований всебічно вірно, скарги на психічне нездоров'я надає неповністю. Пояснює, що останній раз у денному стаціонарі лікувався 2 роки тому. Проживає разом 3 мамою, відносини 3 нею характеризує як хороші, іноді зловживає алкоголем. В останні роки не працює. Мислення 3 явищами зісковзувань, формальності. Темп психічних процесів загальмований. Довільна увага 3 деякими труднощами концентрації. Продуктивність мнестичної діяльності в межах норми. Відмічається емоційна сплощеність, вибірковий негативізм. В останні часи іноді висловлює маячні ідеї; вербальні псевдогалюцинації не виявляються. Критичні здібності до свого психічного стану та виниклої ситуації знижені. Зі слів матері, підекспертний може сам приготувати їжу, але ходити до магазину не може, у цілому відмічається «нерізко-виражений апатико-дисоціатвиний дефект внаслідок шизофренічного процесу, стан нестійкої ремісії».

При психологічному дослідженні відмічено, що підекспертний тримається формально, неохоче підтримує контакт. На стан пам'яті, мислення не скаржиться. Недостатньо критично відноситься до порушень у себе в минулому. Вважає, що «тоді був хворим, а тепер одужав». Підкреслює, що упродовж останніх 2-3 років не лежав у стаціонарах. Ціль експертизи розуміє формально. Темп психічних процесів підекспертного дещо уповільнений. Довільна увага 3 деякими труднощами концентрації. Продуктивність мнестичної діяльності в межах норми. Операції узагальнення та абстрагування призводить на достатньому рівні. На цьому фоні допускає окремі судження, що засновані на латентних ознаках предметів та явищ, однак іноді здатний виправити такі помилки при невеликій спрямовуючій допомозі експерта, тому вони не знижують загальну продуктивність його мислення.

При обгрунтуванні висновку в мотивувальній частині експерти вказують, що, як вбачається 3 аналізу матеріалів цивільної справи, медичної документації, К. страждає стійким хронічним психічним розладом у вигляді «шизофренії, параноїдної форми, безперервно-прогредієнтний тип перебігу»; захворювання дебютувало «гострою галюцинаторно-параноїдною симптоматикою»; багаторазово лікувався в психоневрологічних лікарнях із загостренням; останній раз лікувався в денному стаціонарі 2 роки тому. У підекспертного упродовж останнього року відмічається депресивна симптоматика. Наявність маячних ідей, галюцинацій не відмічено в записах дільничного психіатра, але кожного разу, коли пі- 
декспертний відвідує психіатра з частотою 5-6 разів на рік, йому призначаються підтримуючі ліки.

При останньому відвідуванні дільничного психіатра відмічено, що в підекспертного емоційна сплощеність, мислення паралогічне, критика знижена, продуктивна психотична симптоматика не виявляється. При клінічному дослідженні в підекспертного виявляється «нерізко-виражений апатико-дисоціативний дефект внаслідок шизофренічного процесу»; зниження критики до свого психічного стану, виниклої ситуації, відсутність гострої продуктивної психотичної симптоматики (маячення, галюцинації).

Вищевказані психічні порушення підекспертного відповідають діагностичним критеріям МКХ-10: Шизофренія, параноїдна форма, безперервно-прогредієнтний тип перебігу, нерізко-виражений апатико-дисоціативний дефект, неповна ремісія (F20.04 згідно з МКХ$10)$.

У висновках експерти, відповідаючи на запитання, вказують що К. страждає стійким хронічним психічним розладом: шизофренія, параноїдна форма, безперервнопрогредієнтний тип перебігу, нерізковиражений апатико-дисоціативний дефект, неповна ремісія (F20.04 згідно з МКХ-10), який істотно впливає на його здатність усвідомлювати значення своїх дій та керувати ними. Згідно зі ст. 36 ЦК України може бути визнаним «обмежено дієздатним» та потребує встановлення піклування.

На сьогоднішній день існують різні моделі діагностики психічних розладів, серед яких слід зупинитися на категоріальній (дескриптивній) та операціональній (критеріальній). Категоріальна модель є традиційною для вітчизняної психіатричної школи та грунтується на дескриптивному (описовому) підході. Вона передбачає існування чітких меж між нормою й патологією та окремими нозологічними категоріями. Симптоми психічного розладу розглядаються у ній як ієрархічна сукупність з встановленими причинно-наслідковими відносинами. Синдром являє собою систему взаємопов'язаних симптомів. 3 послідовної зміни синдромів складається клінічна картина хвороби та іiі розвиток. Діагностика психічного розладу грунтується на оцінці динаміки синдромів [7]. Недоліком вказаної моделі є труднощі відтворюваності симптомів психічного захворювання внаслідок недостатності чітких описових характеристик, що при нозологічній кваліфікації ряду станів допускає неоднозначні діагностичні оцінки.

Операційна модель діагностики психічних розладів заснована на одному з напрямків філософії науки - операціоналізмі, коли зміст наукових концептів і конструкцій обумовлюється способами (схемами і практичними й/ або розумовими процедурами) взаємодії суб'єкта 3 об'єктом. Ця модель діагностики заперечує чіткі межі між нормою та патологією i 
окремими діагностичними категоріями. Симптоми психічного розладу розглядаються як такі, що мають однакову діагностичну вагу. Під синдромом розуміється вільне поєднання симптомів. Діагностика психічного розладу грунтується лише на описі набору ознак. Але орієнтація описів на зовні подібні, але якісно різні симптоми, не завжди дозволяє здійснювати їх диференціацію. Операціональний принцип діагностики психічних розладів, зокрема, реалізований в чинній Міжнародної класифікації хвороб 10-го перегляду (МКБ-10), що забезпечує відтворюваність симптомів психічного розладу, однак не завжди дозволяє встановити їх нозологічну достовірність.

Для досягнення поставленої мети нами було розроблено діагностичну карту з діагностичними ознаками різної спрямованості для аналізу. Аналіз здатності до регуляції діяльності на кожному етапі прийняття юридично значущих рішень та його реалізації був проаналізований 3 позицій теорії діяльності $[12,13]$. Тобто, випадки прийняття рішень та реалізації юридично значущих рішень у хворих з психопатологічними проявами були проаналізовані 3 позицій можливих порушень смислових та цільових рівнів регуляції діяльності.

На цьому етапі дослідження логіка обробки отриманих даних була наступною. Спочатку було перевірено гіпотезу про відмінність розподілів у цілому по всіх виводах та всіх градаціях другої ознаки. Інакше кажучи, спочатку ми перевірили вплив ознаки на висновки в цілому. Якщо було отримано значущі відмінності (значущий вплив), то на наступному етапі проводилось уточнення, в яких саме градаціях наявні ці відмінності. Для цього було об'єднано частоти, коли відсотки були близькі. Як і в дисперсійному аналізі, динаміка розвитку в такому випадку - від загального до конкретного. Спочатку було перевірено чи $\epsilon$ взагалі вплив факторів, а потім уточнювалося, в яких градаціях саме. Розглянемо дані по першому етапу аналізу.

При аналізі даних щодо визнаних обмежено дієздатними осіб, було виявлено ряд значущих відмінностей. При проведенні психодіагностичної бесіди було з'ясовано, що статистично значуща більшість осіб або не могла відтворити важливі анамнестичні свідчення, або відтворювала їх частково $\left(\chi_{(12, \mathrm{~N}=60)}^{2}=0,73\right.$, $\mathrm{p}=* *, 026)$, що більш за все пов'язано з порушеннями когнітивних та перш за все мнестичних функцій. А також не повною мірою розуміла мету призначення експертизи, ії задачі та свій правовий статус $\left(\chi_{(12, \mathrm{~N}=60)}^{2}=1,65\right.$, $\mathrm{p}=* *, 011)$, що пов'язано з порушеннями, в тому числі, критичних здатностей $\left(\chi_{(12, \mathrm{~N}=60)}^{2}=\right.$ $5,85, \mathrm{p}=* *, 000)$.

Щодо даних клінічної спрямованості, які стосуються можливих причин виникнення захворювання, особливостей протікання, перебігу, то нами було виявлено значущі розбіжності у наступних показниках. Так, фактор обтяженої спадковості не відігравав значущої 
ролі при вирішенні питання щодо обмеженої дієздатності, оскільки в досліджуваній групі хворих переважна більшість мала органічну патологію, яка не $є$ спадковою, а набута внаслідок атрофічних, судинних процесів тощо $\left(\chi_{(12, \mathrm{~N}=60)}^{2}=0,73, \mathrm{p}=* *, 026\right)$. Також не відмічалась переважна більшість щодо хронічного вживання психоактивних речовин $\left(\chi_{(12, \mathrm{~N}=60)}^{2}=\right.$ $0,19, \mathrm{p}=* *, 003)$.

Розлади психічної діяльності, які призвели до порушення мотивації, критичності, прогнозу $\quad\left(\chi_{(12, \mathrm{~N}=60)}^{2}=0,33, \quad \mathrm{p}=* *, 000\right) \quad$ були поділені на негативні та 3 продуктивною симптоматикою. Це аргументувалось тим, що згідно 3 нашим припущенням, в залежності від «набору» патопсихологічних та психопатологічних ознак, буде прийнято остаточне рішення стосовно призначення піклування або опіки. Це має одне з вирішальних значень при аргументації категорії обмеженої дієздатності, оскільки сприяє не тільки захисту прав хворого, але і його соціальній адаптації. Так, деякі форми психічних захворювань не порушують соціального функціонування особи в реальних (не на момент юридично значущої дії) умовах, i, відповідно, заперечують необхідності призначення над ним опіки. Проте, в таких випадках все одно необхідно мати чіткі критерії для визначення здатності хворого до організації своєї юридично значущої поведінки із врахуванням прогнозу та компенсаторних можливостей хворого.

Аналіз таблиць спряженості довів, що більшість випадків склали випадки 3 негативною симптоматикою помірного ступеню вираженості $\left(\chi_{(12, \mathrm{~N}=60)}^{2}=0,16, \mathrm{p}=* *, 009\right)$, у той час як наявність продуктивної симптоматики не була значущою при винесенні рішення щодо обмеження для даної групи хворих $\left(\chi_{(12, \mathrm{~N}=60)}^{2}=0,89\right.$, $\mathrm{p}=* *, 011)$.

Проаналізовані дані дозволяють зробити припущення, що для оцінки здатності суб'єкта розуміти значення власних дій та здатності до прогнозу та керування такими діями, за необхідне вважається виділення декількох критеріїв: ступеню вираженості змін когнітивних функцій, ступеню вираженості змін емоційно-вольової та мотиваційної сфери, порушення прогностичних та критичних функцій. Аналіз отриманих даних за таблицями спряженості довів, що в групі обмежено дієздатних більшість підекспертних не в повній мірі були здатні розуміти значення власних дій на момент укладення угоди $\quad\left(\chi_{(12, \mathrm{~N}=60)}^{2}=0,24\right.$, $\mathrm{p}=* *, 000)$, що призвело до статистично підтверджених даних щодо більшості випадків, коли угода були визнана недійсною $\left(\chi^{2}\right.$ $(12, \mathrm{~N}=60)=0,28, \mathrm{p}=* *, 000)$.

Щодо показника соціальної дезадаптованості, то він має доволі цікавий та неоднозначний характер та не завжди чіткі параметри при визнанні особи недієздатною або обмежено дієздатною. Тобто відмічається певне протиріччя між вирішенням цього питання та фактичною соціальною адаптацією пацієнта. Найбільш складні випадки стосуються дихо- 
томічних

категорій

«дієздатний-

недієздатний». Тому введення категорії обмеженої дієздатності має і в цьому розумінні певний сенс, оскільки уможливлює іiі використання при певних психічних розладах та в конкретній цивільно-правовій сфері. За нашими даними групу обмежено дієздатних склали особи з помірно вираженим ступенем соціальної дезадаптованості $\left(\chi_{(12, \mathrm{~N}=60)}^{2}=3,29\right.$, $\mathrm{p}=* *, 000)$. До цього показника, наряду з даними щодо когнітивного функціонування, можна віднести також соціальну характеристику здатності до самостійного проживання, яка за нашими даними на цьому етапі аналізу мала двоякий характер, оскільки висока значущість показала переважання ï представленості як 3 неможливістю, так й здатністю до самостійного проживання, що потребує ще додаткового уточнення $\left(\chi_{(12, \mathrm{~N}=60)}^{2}=0,35, \mathrm{p}=* *, 000\right)$. Питання самостійного проживання оцінюється експертами 3 точки зору наявності або відсутності небезпеки самостійного проживання пацієнта. При цьому відсутність небезпеки самостійного проживання розуміється як мінімальний ризик як для самого пацієнта, так і для його оточення. Важливим при цьому стають показники когнітивного функціонування (достатність для розуміння та прийняття рішень, які мають відношення до самостійного проживання) та показники необхідних соціальних навичок (здатність до самообслуговування, здатність до самостійного та незалежного соціального функціонування).
Не було виявлено значущих відмінностей за показниками аутоагресії, агресії, диференційованості в наданні скарг на стан здоров'я, наркотизації, виражених змін психічної діяльності, патології дитинства, дублювання класів, характеристик трудової діяльності та причин, чому не працює.

Висновки. Таким чином доведено, що в умовах зростаючих вимог до обгрунтування експертних висновків, динамічних змін в законодавстві виникає потреба в створенні цілісної системи, яка б сприяла об'єднанню сучасних та традиційних принципів діагностики психічних розладів 3 принципами судово-експертної діяльності з використанням сучасних методів психологічної діагностики.

Важливим в методологічних підходах в судовій експертології у цивільному процесі постають, по-перше, питання законодавчої бази: предмет, об'єкт, підстави та порядок призначення та загальні принципи проведення експертного дослідження. По-друге, врахування загальних принципів судово-експертної діяльності психологів: етапи та методи експертного дослідження з дотриманням всіх вимог, психологічна діагностика розладів психічної діяльності та встановлення патопсихологічних регістр-синдромів, установлення співвідношення медичного та юридичного критеріїв.

\section{Перспективу подальших досліджень} слід вбачати в розробці основних методологічних принципів обгрунтування судовопсихологічного діагнозу, оцінці юридично 
значущих можливостей в судовій експертології. Важливим постає питання розробки нових та удосконалення існуючих діагностичних критеріїв обмеженої дієздатності, що сприятиме оптимізації роботи експертних комісій, уніфікації експертних критеріїв, підвищенню аргументованості експертних висновків i, в кінцевому рахунку, підвищенню якості експертних висновків та зниженню числа повторних судово-психіатричних експертиз.

\section{Перелік використаних джерел:}

1. Первомайский $\quad$ B. $\quad$ Б., Илейко $\quad$ В.Р. Судебнопсихиатрическая экспертиза: от теории к практике К.: КИТ, 2006. - 394 с.

2. Сергєєв О. П., Толстой Ю.К. Гражданское право Учебник: в 3 т. Том 1: - 6-е изд., перераб. и доп. / под ред. Сергеева А. П., Толстого Ю. К. - М. : ТК Велби, Изд-во Проспект, 2005. - 776 с.

3. Шостакович Б. В. Основы судебной психиатрии. Учебное пособие для юристов. М., Издательский дом ГУ ВШЭ, 2005.

4. Ратинов А. Р. Социально-психологические аспекты юридической теории и практики / А.Р.Ратинов // Прикладная социальная психология. - М.: Наука, 1981. C.213.

5. Ломов Б. Ф. Методологические и теоретические проблемы психологии / Ломов Б.Ф. - М.: Наука, 1984. $444 \mathrm{c}$.

6. Шостакович Б. В., Ревенок А. Д. Психиатрическая экспертиза в гражданском процессе. - Киев: Здоров'я, 1992. - 184 c.

7. Ткаченко $A$. А. Экспертное судебно-психиатрическое исследование: подготовительная и аналитическая стадии. // Российский психиатрический журнал. - 2005. - № 3. - C. 44-50.
8. Корзун Д. Н., Ткаченко А.А. Судебнопсихиатрическая оценка механизмов принятия юридически значимых решений // Рос. психиатр. журн. - 2013. - № 1. - С. 11-17. 14.

9. Кудрявщев И. А. Судебная психологопсихиатрическая экспертиза. - М.: Юрид. лит., 1988. — 224 c.

10. Костицький М. В. Судебно-психологическая экспертиза. Монография / Костицкий М.В. - Львов: Вища шк., 1987. - $140 \mathrm{c}$.

11. Марчук A. I. Судова психіатрія: навч.посібник / А.І.Марчук.- К.: Атіка, 2004. - 240с.

12. Леонтьєв О. М., Деятельность, сознание, личность. М.: Политиздат, 1975. - 304 с.

13. Братусь Б. С. Аномалии личности.- М.: Мысль, 1988.- 301 c.

\section{References (Transliteration):}

1. Pervomajskij V. B., Ilejko V.R. Sudebnopsihiatricheskaya ehkspertiza: ot teorii k praktike K.: KIT, 2006. - $394 \mathrm{~s}$.

2. Sergeev O. P., Tolstoj YU.K. Grazhdanskoe pravo Uchebnik: v 3 t. Tom 1: - 6-e izd., pererab. i dop. / pod red. Sergeeva A. P., Tolstogo YU. K. - M. : TK Velbi, Izd-vo Prospekt, 2005. - $776 \mathrm{~s}$.

3. Shostakovich B. V. Osnovy sudebnoj psihiatrii. Uchebnoe posobie dlya yuristov. M., Izdatel'skij dom GU VSHEH, 2005.

4. Ratinov A. R. Social'no-psihologicheskie aspekty yuridicheskoj teorii i praktiki / A.R.Ratinov // Prikladnaya social'naya psihologiya. - M.: Nauka, 1981. -S.213.

5. Lomov B. F. Metodologicheskie i teoreticheskie problemy psihologii / Lomov B.F. - M.: Nauka, 1984. 444s.

6. Shostakovich B. V., Revenok A. D. Psihiatricheskaya ehkspertiza v grazhdanskom processe. - Kiev: Zdorov'ya, 1992. - $184 \mathrm{~s}$.

7. Tkachenko A. A. Ehkspertnoe sudebno-psihiatricheskoe issledovanie: podgotovitel'naya i analiticheskaya stadii. // 
Rossijskij psihiatricheskij zhurnal. - 2005. - № 3. - S. 44-50. 8. Korzun D. N., Tkachenko A.A. Sudebnopsihiatricheskaya ocenka mekhanizmov prinyatiya yuridicheski znachimyh reshenij // Ros. psihiatr. zhurn. 2013. - № 1. - S. 11-17. 14.

9. Kudryavcev I. A. Sudebnaya psihologo-psihiatricheskaya ehkspertiza. — M.: YUrid. lit., 1988. - 224 s.

10.10. Kostic'kij M.V. Sudebno-psihologicheskaya ehkspertiza. Monografiya / Kostickij M.V. - L'vov: Vishcha shk., 1987. - $140 \mathrm{c}$.

11. Marchuk A. I. Sudova psihiatriya: navch.posibnik A.I.Marchuk.- K.: Atika, 2004. - 240s.

12. Leont'ev O. M., Deyatel'nost', soznanie, lichnost'. M.: Politizdat, 1975. - 304 s.,

13. Bratus' B. S. Anomalii lichnosti.- M.: Mysl', 1988.$301 \mathrm{~s}$.

\section{Zaviazkina Natalia}

Ph. D. in Psychological sciences, Associate Professor of The Departments of Clinical Psychology of Taras Shevchenko Kyiv National University, Kyiv (Ukraine)

CLINICAL AND PSYCHOLOGICAL ASSESSMENT OF THE LIMITED RESPONSIBILITY TO "UNDERSTAND, EVALUATE AND MAKE DECISIONS" IN THE CIVIL PROCESS

\section{ABSTRACT}

Growing demands for substantiating expert opinions, and dynamic changes in legislation, dictate the need for create an integrated system that would facilitate the unification of modern and traditional principles of diagnosing mental disorders with the principles of forensic expert activity using modern methods of psychological diagnosis.

One of the most important tasks during the examinations in the civil process is the development of diagnostic criteria for limited legal capacity, the establishment of its "lower" and "upper" boundaries. This is especially important in view of the fact that the partial possibility of a limitedly capable citizen to be responsible (to understand the meaning of one's own actions and the need to fulfill obligations, the ability to retain them in memory, the ability to perform actions under external regulations on the part of the trustee) is one of the significant grounds for differentiation of the limited incapacity and incapacity.

In the course of the research it was proved that the growing demands for substantiating expert opinions, and dynamic changes in legislation, dictate the need for create a integrated system that would facilitate the unification of modern and traditional principles of diagnosing mental disorders with the principles of forensic expert activity using modern methods of psychological diagnosis.

Important questions in the methodological approaches in forensic expertology in the civil process are, firstly, the issue of the legislative framework: the subject, the object, the grounds and the order of appointment and the general principles of conducting expert research. Secondly, the consideration of general principles of forensic expert activity of psychologists: stages and methods of expert research with observance of all requirements, psychological diagnosis of mental disorders and the establishment of pathopsychological register-syndromes, establishing the correlation between medical and legal criteria. 
Analyzed data suggest that to assess the ability of the subject to understand the significance of their actions and the ability to predict and manage such actions, it is necessary to identify several criteria: the degree of manifestation of changes in cognitive functions, the degree of expression of changes in the emotional-volitional and motivational sphere, the violation of prognostic and critical functions.

Key words: psychological assessment, limited responsibility, limited legal responsibility, civil process, psychodiagnostics, psychological examination.

\section{Завязкина Наталия Владимировна}

Кандидат психологических наук, доцент факультета психологии Киевского наџионального университета имени Тараса Шевченко, г. Киев (Украина)

\section{КЛИНИКО-ПСИХОЛОГИЧЕСКАЯ ОЦЕНКА ОГРАНИЧЕННОЙ СПОСОНОСТИ «ПОНИМАТЬ, ОЦЕНИВАТЬ И ПРИНИМАТЬ РЕШЕНИЯ» В ГРАЖДАНСКОМ ПРОЦЕССЕ}

Аннотация. В условиях растущих требований к обоснованию экспертных заключений, динамических изменений в законодательстве возникает потребность в создании целостной системы, которая бы способствовала объединению современных и традиционных принципов диагностики психических расстройств с принципами судебно-экспертной деятельности с использованием современных методов психологической диагностики. При проведении экспертиз в гражданском процес- се одной из важнейших задач становится разработка диагностических критериев ограниченной дееспособности, установление ее «нижней» и «верхней» границы. Это особо актуально в связи с тем, что частичная возможность ограниченно дееспособного гражданина нести ответственность (понимать значение собственных поступков и необходимость выполнения обязательств; способности удержание их в памяти, возможности выполнять действия в условиях внешней регламентации со стороны попечителя) составляет одно из значимых оснований дифференциации ограниченной дееспособности и недееспособности. В ходе исследования доказано, что в условиях растущих требований к обоснованию экспертных заключений, динамических изменений в законодательстве возникает потребность в создании целостной системы, которая бы способствовала объединению современных и традиционных принципов диагностики психических расстройств с принципами судебно-экспертной деятельности с использованием современных методов психологической диагностики. Важными компонентами в методологических подходах в судебной экспертологии в гражданском процессе выступают, во-первых, вопрос законодательной базы: предмет, объект, основания и порядок назначения и общие принципы проведения экспертного исследования; во-вторых, учет общих принципов судебно-экспертной деятельности психологов: этапы и методы экспертного ис- 
следования с соблюдением всех требований, психологическая диагностика расстройств психической деятельности и установление патопсихологических регистр-синдромов, установления соотношения медицинского и юридического критериев. Проанализированные данные позволяют предположить, что для оценки способности субъекта понимать значение своих действий, его способности к прогнозу и управления такими действиями, необходимо выделение нескольких критериев: степени выраженности изменений когнитивных функций, степени выраженности изменений эмоционально-волевой и мотивационной сферы, нарушения прогностических и критических функций.

Ключевые слова: психологическая оценка, ограниченная дееспособность, гражданский процесс, психодиагностика, психологическая экспертиза. 